\title{
Federal Tax Incentives Encourage Alternative Fuel Use
}

Through a variety of legislative acts, the U.S. government provides several tax incentives for purchasing alternative fuel, hybrid electric, and fuel cell vehicles; installing alternative fueling infrastructure; and producing, selling, or using alternative fuels. ${ }^{*}$ These incentives, which are outlined in the Internal Revenue Code (IRC), have been established to encourage the commercialization of advanced fuels and vehicle technologies to reduce our nation's dependence on imported oil.

Tax incentives related to alternative fuels are the subject of this fact sheet. Fleet operators, fuel providers, fuel blenders, and certain other individuals may be able to take advantage of credits for alternative fuels they produce, sell, and use. There are many conditions, particularly with regard to fuel composition, the manner in which the fuel is used, and who is ultimately responsible for paying the excise tax, that must be satisfied to qualify for a given incentive.

This fact sheet provides an overview of these incentives to inform you of tax credits that may be available; however, the filing process can be complex and you should consult with your tax advisor when registering and filing for these tax credits.

\section{Significant Impacts}

The American Jobs Creation Act of 2004 (Jobs Bill), the Safe, Accountable, Flexible, Efficient Transportation Equity Act: A Legacy for Users (Highway Bill), and the Energy Policy Act of 2005 (EPAct 2005) have all had a significant impact on the IRC.

Through these legislative acts, certain alternative fuels were added to the Volumetric Excise Tax Credit (VEETC), the Nontaxable Use of Alternative Fuel Credit was established, new tax incentives were created for small producers of ethanol and biodiesel, and some already existing tax credits were extended to further support the industry. Changes have been made to the IRC to include these new tax incentives, though, interpreting them can be challenging.

\section{Massachusetts Transit Fleet Reaps "Unexpected" Rewards for CNG Use}

The new federal fuel tax credits are good incentives for alternative fuel providers and even better incentives for taxexempt organizations like government fleets.

In November, 2007, the Massachusetts Bay Transportation Authority (MBTA) received a $\$ 1.8$ million tax credit from the IRS for its compressed natural gas (CNG) use and

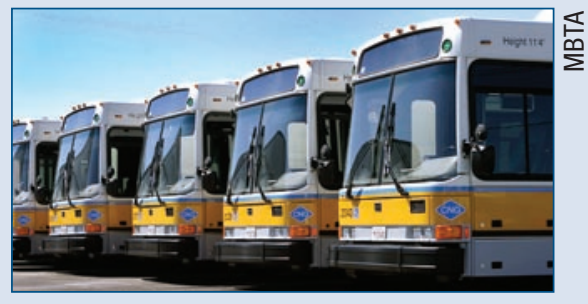

MBTA operates 360 CNG buses. expects to receive approximately $\$ 600,000$ from the IRS every quarter until the credit expires.

Informed by a Clean Cities stakeholder that the Alternative Fuel Tax Credit was available to both taxable and tax-exempt organizations, MBTA did the math and realized they were missing out on a credit they were entitled to. "This is money we did not expect," said MBTA General Manager Daniel Grabauskas.

The fuel tax credit of $\$ .50$ per GGE of CNG began on October 1 , 2006 and ends on September 30, 2009. For the MBTA, that equates to approximately $\$ 7.4$ million in tax credits over three years.

According to their Web site, the MBTA is the nation's 5th largest mass transit system serving a population of $4,667,555$ in an area of 3,244 square miles. The MBTA operates over 1,000 buses of which 360 are CNG buses.

\section{IRS Defines "Alternative Fuels"}

One of the most noteworthy changes to the IRC is the addition of a clear definition of the fuels that fall under the "alternative fuels" category. Alternative fuels, as defined by the IRS, are: liquefied petroleum gas (LPG), compressed natural gas (CNG), liquefied natural gas (LNG), liquefied

\footnotetext{
* Summaries of these incentives are available on the Incentives and Laws section of the Alternative Fuels and Vehicles Data Center Web site at www.eere.energy.gov/afdc/progs/fed_summary/php/afdc/US/0. Please refer to this Web site for current information and applicable expiration dates.
} 
hydrogen, liquid fuel derived from coal (including peat) through the Fischer-Tropsch process, liquid hydrocarbons derived from biomass, and P-Series fuels. While the term "hydrocarbons" includes liquids that contain oxygen, hydrogen, and carbon and as such "liquid hydrocarbons derived from biomass" from a chemical standpoint includes ethanol, and biodiesel and renewable diesel, the IRS chose not to include these fuels in the alternative fuels category. Tax incentives for these fuels are covered under the fuel categories of gasoline and diesel, respectively.

\section{Excise Tax \& Excise Tax Exemptions for Nontaxable Use of Transportation Fuels}

Excise taxes are taxes paid when purchases are made of certain goods and are often included in the price of the product. More specifically, excise taxes are applied to the consumption of motor fuels. The use of certain forms of gasoline, kerosene, diesel, and more recently alternative fuels in a motor vehicle benefit from an exemption of this tax when the fuel is used in a manner that the IRS deems a "nontaxable use." The exemption is treated as a credit to offset the excise tax initially imposed on the fuel.

It is important to note that although E85 and biodiesel are not considered alternative fuels by the IRS, E85 and certain biodiesel blends, depending on paraffin content, are taxed in the same category as gasoline and diesel.

Current excise taxes for the most popular alternative fuels are \$.183 per gallon of LPG or gasoline gallon equivalent (GGE) of CNG, and \$.243 per gallon of LNG. The excise tax on ethanol is $\$ .183$ per gallon and biodiesel and renewable diesel are taxed at $\$ .243$ per gallon.

Some of the more common nontaxable uses for fuels in a motor vehicle are:

- On a farm for farming purposes

- Off-highway business use

- In certain intercity and local buses

- In a school bus

- Exclusive use by a nonprofit educational organization

- Exclusive use by a state, political subdivision of a state, or the District of Columbia.

IRS CAUTION: If you make a claim for alcohol, biodiesel or renewable diesel, or alternative fuel used to produce a mixture, a claim for refund or credit on Form 8849, Form 4136, Form 6478, or Form 8864 can only be made after the sum of the alcohol fuel mixture credit, biodiesel or renewable diesel mixture credit, and alternative fuel mixture credit is first applied to reduce your taxable fuel liability. See the instructions for Form 720, Quarterly Federal Excise Tax Return.

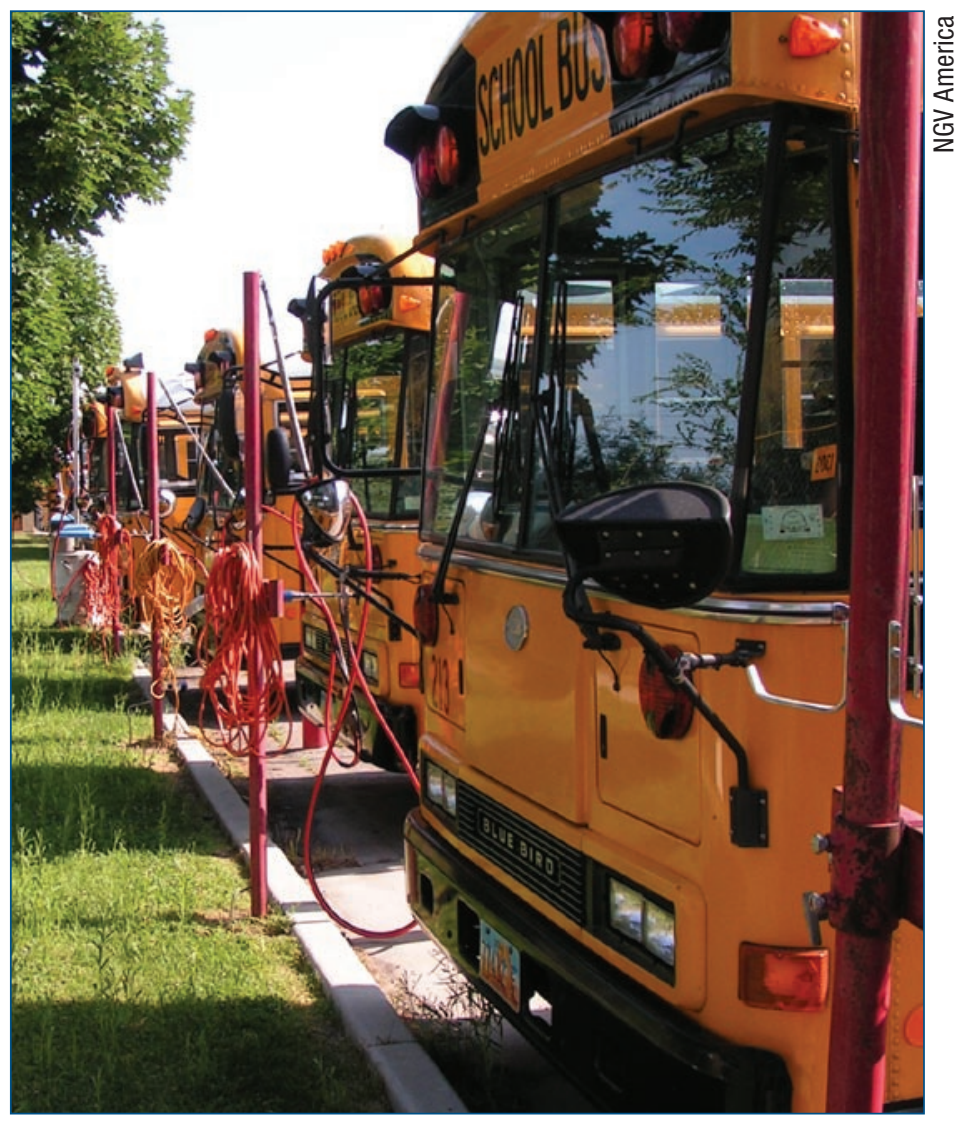

School buses at a CNG refueling station.

According to the IRS, the person generally responsible for reporting and paying the federal excise tax is the person that also takes the credit. This exemption is not available to tax-exempt entities that are not liable for excise tax on transportation fuel. See the instructions for IRS Form 720, Quarterly Federal Excise Tax Return, for more details.

\section{Credits for Users, Sellers, and Producers of Alternative Fuels, Biodiesel, and Fuel Mixtures}

Alternative fuel credits, biodiesel or renewable diesel credits, and fuel mixture (including ethanol/gasoline blends) credits were established in the VEETC portion of the Jobs Bill and are meant to provide incentives to produce, sell, and use these fuels. Credits range from $\$ .50$ to $\$ 1$ per gallon or GGE, far exceeding the federal excise tax imposed on the fuel. They extend to both taxable, including private fleets, and tax-exempt organizations including state, local, and tribal governments, as well as non-profit and other tax-exempt organizations. The form of the return is a direct payment from the IRS for tax-exempt organizations or a tax credit for taxable organizations.

This means that government fleets that do not normally pay taxes on transportation fuels are eligible for a fuel credit in the form of a direct payment in the amount of $\$ .50$ or $\$ 1$ for every gallon or GGE of alternative fuel or 


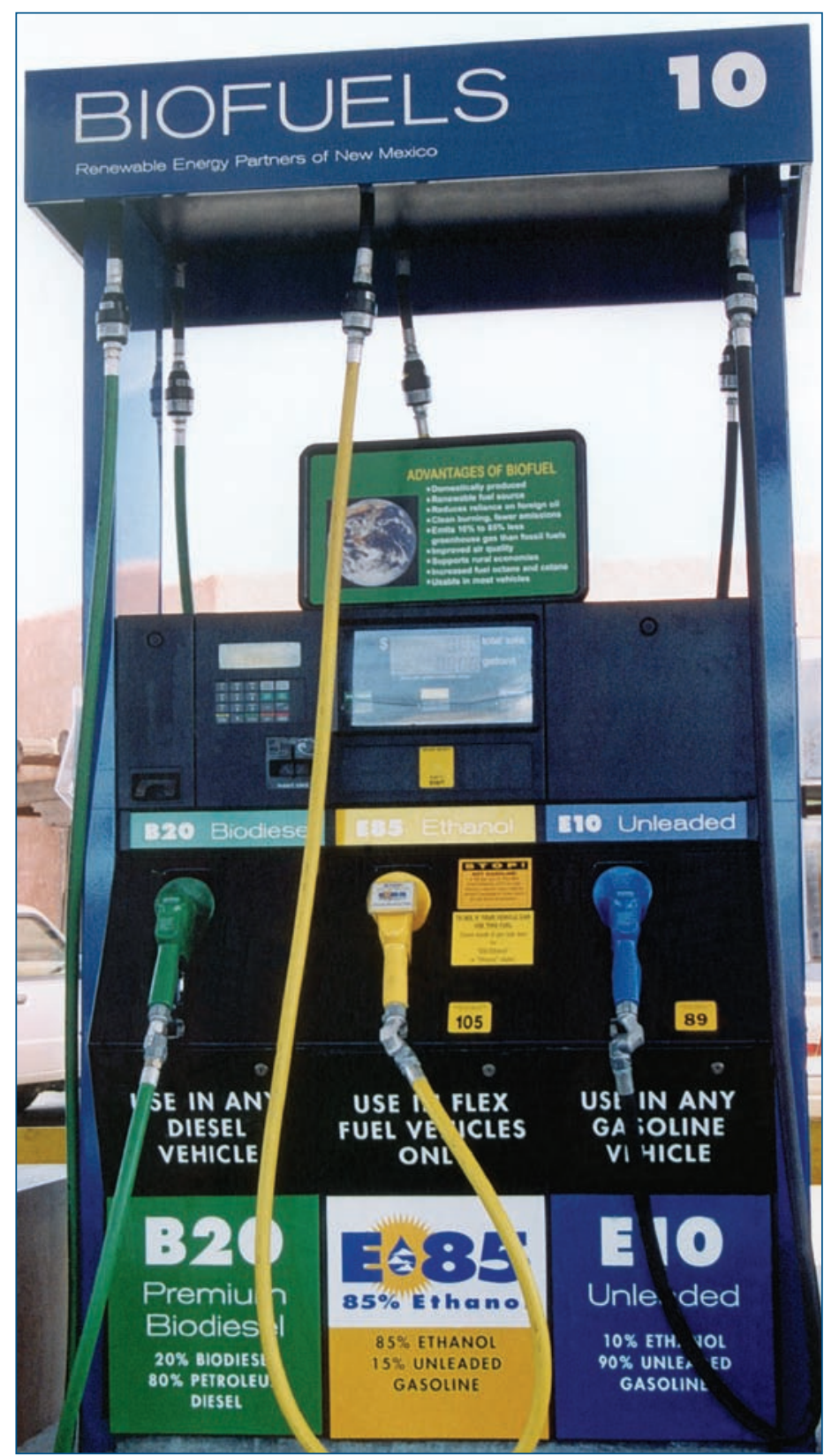

Federal excise tax is reflected in retail pump prices per gallon or GGE.

biodiesel used. For fleets that use large quantities of fuel, these credits can equate to millions of dollars.

To claim any of these credits, you must be registered with the IRS as either a producer, blender, or an alternative fueler, depending on which credit is being claimed. See IRS Form 637, Application for Registration (for Certain Excise Tax Activities).

\section{Alternative Fuel Credit}

The Alternative Fuel Credit is $\$ .50$ per gallon or GGE and applies to alternative fuels as defined by the IRS. Credits for these fuels may be claimed by anyone who is registered with the IRS and:
- uses the fuel in their trade or business

- sells the alternative fuel at retail and places it in the fuel tank of a buyer's vehicle

- sells the alternative fuel at retail and delivers it to the buyer in bulk for a taxable use in a motor vehicle (seller must obtain a statement from the buyer acknowledging the taxable use).

\section{Biodiesel or Renewable Diesel Credits (including agri-biodiesel)}

EPAct 2005 extended the excise tax provisions for biodiesel through 2008 and established new credits for agri-biodiesel and renewable diesel.

- The fuel tax credit for biodiesel is $\$ .50$ per gallon, where biodiesel is defined as the monoalkyl esters of long chain fatty acids derived from plant or animal matter which meet the registration requirements for fuels and fuel additives established by the Environmental Protection Agency (EPA) under section 211 of the Clean Air Act.

- The fuel tax credit for agri-biodiesel is $\$ 1$ per gallon, where agri-biodiesel is defined as diesel fuel derived solely from virgin oils, including esters derived from virgin vegetable oils from corn, soybeans, sunflower seeds, cottonseeds, canola, crambe, rapeseeds, safflowers, flaxseeds, rice bran, and mustard seeds, and from animal fats.

- The fuel tax credit for renewable diesel is \$1 per gallon, where renewable diesel is diesel fuel derived from biomass using a thermal depolymerization process.

Credits for these fuels may be claimed by anyone who purchases the fuel directly from the producer or reseller and uses the fuel in their trade or business, or by anyone who sells pure biodiesel at retail and places it in the fuel tank of a buyer's vehicle. In both circumstances, a Certificate for Biodiesel from the producer is required to claim the payment or credit. No credit is available for fuel used in a trade or business that was purchased in a retail sale.

\section{Fuel Mixture Credits}

Mixture credits require that the fuel was produced by mixing a taxable fuel with an alternative fuel or, in the case of the Alcohol Fuel Mixture Credit, with alcohol. Producers, who may also be blenders, that produce the mixture for sale or use the mixture in their businesses, take the credit for these fuels and must be registered with the IRS as a producer or blender to do so. These credits are allowable only on the gallons of fuel mixed with the taxable fuel. For example, a fuel mixture credit for E85 (85\% ethanol, 15\% gasoline) at $\$ .51$ per gallon of ethanol will yield a credit of $\$ .4335$ per gallon of E85.

- The Biodiesel or Renewable Diesel Mixture Credit encompasses biodiesel, agri-biodiesel, and renewable 
diesel mixtures. The credit for a biodiesel fuel mixture is $\$ .50$ for every gallon of pure biodiesel used in the fuel mixture. Agri-biodiesel and renewable diesel credits are $\$ 1$ for every gallon of each fuel, respectively, used in the blend.

- The Alternative Fuel Mixture Credit is $\$ .50$ per gallon of pure alternative fuel used in the fuel mixture.

- The Alcohol Fuel Mixture Credit is \$.51 per gallon of alcohol used in the fuel mixture. According to the IRS, the term alcohol, for purposes of this credit, includes ethanol.

\section{Small Ethanol and Small Agri-Biodiesel Producer Tax Credit}

EPAct 2005 changed the definition of a small producer from one producing "up to 30 million gallons per year" to one producing "up to 60 million gallons per year" and created a similar credit for small agri-biodiesel producers. Both the Qualified Ethanol Producer Credit and the Qualified Agri-Biodiesel Producer Credit is a \$.10 per gallon income tax credit for small producers. The credit applies only to the first 15 million gallons of production in a tax year and caps at $\$ 1.5$ million annually. Both of these credits expire December 31, 2008.

\section{Applicable Tax Forms}

The following forms and instructions on how to file a claim can be found at the IRS' Forms and Publications Web site at www.irs.gov/formspubs/index.html.

- Publication 510, Excise Taxes for 2007

- Form 637, Application for Registration (For Certain Excise Tax Activities)

- Form 720, Quarterly Federal Excise Tax Return

- Form 4136, Credit for Federal Tax Paid on Fuels

- Form 8849, Claim for Refund of Excise Taxes

- Form 6478, Credit for Alcohol Used as Fuel

- Form 8864, Biodiesel and Renewable Diesel Fuels Credit

For more information contact the Excise Tax Branch of the Internal Revenue Service at 202-622-3130.

Sponsored by the U.S. Department of Energy Energy Efficiency and Renewable Energy

Vehicle Technologies Program

For more information contact: EERE Information Center 1-877-EERE-INF (1-877-337-3463) www.eere.energy.gov

Prepared by the National Renewable Energy Laboratory (NREL) NREL is a U.S. Department of Energy National Laboratory Operated by Midwest Research Institute $\bullet$ Battelle
A Strong Energy Portfolio for a Strong America

Energy efficiency and clean, renewable energy will mean a stronger economy, a cleaner environment, and greater energy independence for America. Working with a wide array of state, community, industry, and university partners, the U.S. Department of Energy's Office of Energy Efficiency and Renewable Energy invests in a diverse portfolio of energy technologies.

DOE/GO-102008-2501 • May 2008

Printed with a renewable-source ink on paper containing at least 50\% wastepaper, including $10 \%$ postconsumer waste. 